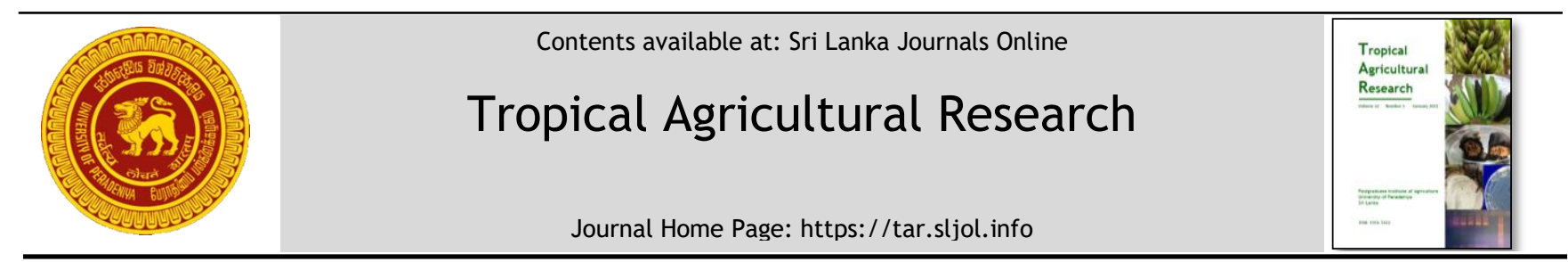

\title{
Biofilm Forming Ability of Broiler Chicken Meat Associated Salmonella spp. on Food Contact Surfaces
}

T.S.P. Jayaweera ${ }^{1}$, H.A.D. Ruwandeepika ${ }^{1}$, V.K. Deekshit ${ }^{2}$, S.P. Kodithuwakku³ ${ }^{3}$, H.W. Cyril ${ }^{3}$, I. Karunasagar ${ }^{2}$ and J.K. Vidanarachchi ${ }^{3 *}$

${ }^{1}$ Department of Livestock Production, Faculty of Agricultural Sciences, Sabaragamuwa University of Sri Lanka, Belihuloya, Sri Lanka.

${ }^{2}$ UNESCO Microbial Resources Centre for Biotechnology, Faculty of Biological Sciences, Nitte University Centre for Science Education and Research, Nitte (Deemed to be University), Deralakatte, Mangalore, India.

${ }^{3}$ Department of Animal Science, Faculty of Agriculture, University of Peradeniya, Peradeniya, Sri Lanka.

\section{ARTICLE INFO}

\section{Article history}

Received: 01 July 2020

Revised version received: 10 October 2020

Accepted: 05 November 2020

Available online: 1 January 2021

\section{Keywords:}

Biofilm

Broiler chicken meat

Food contact surfaces

Regulatory genes

Salmonella

\section{Citation:}

Jayaweera, T.S.P., Ruwandeepika, H.A.D., Deekshit, V.K., Kodithuwakku, S.P., Cyril, H.W., Karunasagar, I. and Vidanarachchi, J.K. (2021). Biofilm Forming Ability of Broiler Chicken Meat Associated Salmonella spp. on Food Contact Surfaces. Tropical Agricultural Research, 32(1): 17-26.

DOI: http://doi.org/10.4038/tar.v32i1.8438

Jayaweera, T.S.P.

https://orcid.org/0000-0002-8722-0529

\section{ABSTRACT}

Biofilms in the meat industry pose a significant impact on public health as many foodborne pathogens can form biofilms on equipment and utensils in meat processing plants. Biofilms formed on contact surfaces could be a continuous source of contaminants to food that come in contact with them. In the present study biofilm-forming ability of different Salmonella spp. isolated from broiler chicken meat from Sri Lanka was quantified, the presence of biofilm-related genes was investigated, and comparative evaluation on the biofilm formation on plastic, stainless steel, and glass surfaces was performed. It was revealed that the biofilm formation increased as a response to the nutrient stress. Quantification of biofilm formation by the microtitre plate method showed 7 strong (30.4\%), 11 moderate (47.8\%), and 5 weak (21.7\%) biofilm formers at low nutrient media (TSB diluted 1:100), whereas there were only 4 moderate biofilm formers and 19 weak biofilm formers found in the undiluted TSB medium. All biofilm formers exhibited the presence of both $a d r A$ and $g c p A$ regulatory genes. Investigation on the ability of biofilm formation on glass, stainless steel, and plastic at time points of $48,96,144,192$, and $240 \mathrm{hrs}$ post incubation with the contamination of $10^{6} \mathrm{CFU} / \mathrm{cm}^{2}$ revealed a significant $(\mathrm{p} \leq 0.05)$ variation among Salmonella isolates. All the isolates illustrated the highest ability to form biofilms on plastic, whereas that was minimum on stainless steel.

*Corresponding author : janakvid@pdn.ac.lk 


\section{INTRODUCTION}

Non-typhoidal Salmonella spp. are among the most commonly encountered foodborne and waterborne pathogens worldwide, and it is the second most reason for the gastroenteritis after the Campylobacter spp. distributed worldwide (Lamas et al., 2018). This spp. gets prime attention as it is an important organism leading to public health issues, and causes a zoonotic bacterial threat in the poultry industry (Merino et al., 2019). The most common route of transmission of Salmonella from animals to humans is through contaminated food or foodstuffs, particularly eggs, egg products, poultry meat, and dairy products (EFSA, 2017). One of the most common food contamination routes is food contact surfaces which are used in food processing (Srey et al., 2013).

In addition to invading the host cells and multiplying, Salmonella spp. are known to possess the capability of surviving outside the host in a sessile form attaching to surfaces as biofilms (Srey et al., 2013). This phenomenon plays a major role in spreading the organism as biofilms which are much more resistant to disinfectants and chemicals (Bhowmick et al., 2011; Borges et al., 2018; Galie et al., 2018). Biofilms are structured communities of microbial cells and they are complex consortia of microorganisms enmeshed in a self-produced matrix of extracellular polymeric substances (EPS) adherent to inert or living surfaces. Many of the foodborne pathogens have the ability to form biofilms on various surfaces such as plastic, metal, glass, aluminum, wood, and other surfaces in different structures in food processing plants such as floors, pipes, drainage, and walls (Schonewille et al., 2012; Wang et al., 2013; Winkelstroter et al., 2014). Biofilm formation by pathogenic bacteria has a great impact on the food industry, sometimes leading to fatal consequences. Its impact is extended to some other areas such as medicine, dentistry, veterinary medicine, water treatment, all of which directly effect human health and life (Feng et al., 2015). The ability of biofilm formation by different Salmonella spp. has shown to be straindependent, and related to the properties of cell surface structures. It has also been proven that biofilms have different abilities to resist different sanitizers and antibiotics at different levels (Wang et al., 2017).

The EPS of Salmonella biofilm is majorly composed of curli (amyloid fimbriae), cellulose, biofilmassociated protein (Bap), 0 -antigen capsule and extracellular DNA. The synthesis of these EPS substances is regulated by a cascade of complex regulatory mechanisms in combination with several genes. The main control unit in biofilm formation is the csgDEFG operon. Some genes such as $\operatorname{csg} D$ of the operon positively regulate $\operatorname{csg} B A$ and adrA expression which is important in biofilm formation of Salmonella spp. (Bhowmick et al., 2011; Steenackers et al., 2012). The protein AdrA (coded by the gene $a d r A$ ) controls the levels of cyclic di-GMP which is important in regulating the cellulose production and thereby the biofilm formation (Garcia et al., 2004). GcpA protein, which is the GGDEF domain containing protein A coded by gcpA gene, plays a critical role in biofilm formation of $S$. typhimurium under low nutrient conditions (Garcia et al., 2004; Bhowomick et al., 2011).

Biofilm formation in food processing environments is of special importance as it has the potential to act as the chronic source of microbial contamination that may lead to food spoilage or transmission of diseases. The knowledge on Salmonella biofilm formation occurring on food contact surfaces is vital to take necessary precautions to avoid possible contaminations of food. In the present study, the biofilm forming ability of different Salmonella spp. which were isolated from broiler chicken meat was quantified, and the presence of related genes of biofilm formation were investigated. Further, a comparative evaluation of the biofilm formation on plastic, stainless steel, and glass surfaces was performed.

\section{METHODOLOGY}

\section{Quantification of biofilm formation using the microtitre plate method}

The study accommodated 23 PCR-confirmed Salmonella isolates collected from different areas of the country. Biofilm formation was quantified in polystyrene microtitre plates following a method described by Stepanovic et al. (2004). Accordingly, 96 well flat-bottomed polystyrene microtiter plates (Grenier Bio-one, Germany) were filled with $230 \mu \mathrm{L}$ of TSB and 1:100 diluted TSB. Twenty microliters from each of the Salmonella isolates cultured for 16 hours was added to each well. The experiment was performed in three replicates. TSB medium without bacterial inoculums was used as the control. The microtitre plates were incubated at $28{ }^{\circ} \mathrm{C}$ for $24 \mathrm{hrs}$. The contents of the well were then discarded and washed thrice with sterile phosphate-buffered saline (PBS) of pH 7.4. Cells attached to the wells of the microtitre plates were fixed with methanol and subsequently stained with $1 \%$ crystal violet. Following the staining step, the stained, attached cells were resolubilized with 33\% (v/v) glacial acetic acid. The Isolates were then classified as strong, moderate, weak, and nonbiofilm producers based on the absorbance values measured at $630 \mathrm{~nm}$ (OD630) in an ELISA reader 
(ELx 800, Bio-Tek, 100 Tigan Street, Winooski, VT05404, USA) (Stepanovic et al., 2000). Optical Density (OD) values of the sterile controls were subtracted from the test values to obtain the 'true' biofilm level. Briefly, the cut-off $\mathrm{OD}\left(\mathrm{OD}_{\mathrm{c}}\right)$ was defined as three standard deviations above the mean OD of the negative control. Isolates were classified as follows:

$\mathrm{OD} \leq \mathrm{OD}_{\mathrm{c}}=$ no biofilm producer,

$\mathrm{OD}_{\mathrm{c}}<\mathrm{OD} \leq\left(2 \times \mathrm{OD}_{\mathrm{c}}\right)=$ weak biofilm producer,

$\left(2 \times \mathrm{OD}_{\mathrm{c}}\right)<\mathrm{OD} \leq\left(4 \times \mathrm{OD}_{\mathrm{c}}\right)=$ moderate biofilm producer, and

$\left(4 \times \mathrm{OD}_{\mathrm{c}}\right)<\mathrm{OD}=$ strong biofilm producer.

\section{Screening for genes responsible for biofilm formation}

The presence of some biofilm-associated genes adrA and gcpA in all 23 Salmonella isolates was checked by using polymerase chain reaction (PCR) as described by Bhowmick et al. (2011). The genomic DNA was extracted according to Ausubel et al. (1992). The purity and concentration of extracted DNA were checked spectrophotometrically by using the NanoDrop spectrophotometer (ND-1000, V3.3.0, Thermo Fisher Scientific, USA).

The PCR was performed in $30 \mu \mathrm{l}$ volumes containing $3 \mu \mathrm{l}$ of $10 \mathrm{X}$ buffer $(100 \mathrm{mM}$ Tris- $\mathrm{HCl}(\mathrm{pH}$ 9) $1.5 \mathrm{mM} \mathrm{MgCl}_{2}, 500 \mathrm{mM} \mathrm{KCl}, 0.1 \%$ Gelatin), 200 $\mu \mathrm{M}$ concentrations each of deoxyribonucleotide triphosphates (dATP, dTTP, dGTP and dCTP), 10 picomoles of each primer and 1.0 U of Taq DNA polymerase (GeneiTM, Merck Bioscience, Bangalore), with $2.0 \mu \mathrm{l}$ of template DNA. The reactions were carried out using a thermal cycler (BioRad, CA, USA). The PCR products were resolved in $1.5 \%$ agarose gel, stained with ethidium bromide ( $5 \mathrm{ng} \mathrm{ml}^{-1}$ ) and bands were visualized and documented using a gel documentation system (Herolab, Wiesloch, Germany).

\section{Biofilm formation on different surfaces}

The ability of Salmonella isolates to form biofilm on glass, stainless steel, and plastic food contact surfaces was determined at different post incubation time points $(48,96,144,192$, and 240 hrs) with $10^{6} \mathrm{CFU} / \mathrm{cm}^{2}$ of bacteria. Based on the results of the biofilm quantification experiment, three strong biofilm producers (isolates S4, S6, and S23) and one moderate biofilm producer (isolate S8) were selected for the study. Bacterial cultures were recovered from stock on Luria Bertani Agar
(Himedia, India) and a single colony was used for the study.

All surfaces were properly sterilized before use as described by Joseph et al. (2001) and Marques et al. (2007). The prepared surfaces (glass, stainless steel, and plastic) were separately placed in Petri dishes and $40 \mathrm{~mL}$ of Luria-Bertani medium (LB broth) was added to each petri dish for conditioning.

A single colony from each Salmonella isolate was grown in LB broth for $24 \mathrm{~h}$ at $37^{\circ} \mathrm{C}$ and cells were washed twice in sterile distilled water following incubation. Bacterial cell numbers were determined spectrophotometrically, and $10^{5}$ $\mathrm{CFU} / \mathrm{mL}$ bacterial cells were inoculated to each conditioned Petri plate which contained LB broth and surface materials. After incubation at ambient temperature $\left(28 \pm 2^{\circ} \mathrm{C}\right)$ for $72 \mathrm{hrs}$, the samples were aseptically removed, washed in sterile phosphate buffer saline (PBS, pH 7.4) in order to remove unattached cells. This procedure was repeated twice in 72-hour time intervals to complete the biofilm formation (Joseph et al., 2001). Experiments were done in three individual replicates. Surface samples without Salmonella spp. were used as the uncontaminated control to determine the sterility of surface samples.

Bacterial cells were enumerated at five different time points as $2^{\text {nd }}, 4^{\text {th }}, 6^{\text {th }}, 8^{\text {th }}$, and $10^{\text {th }}$ day of the incubation. At each time interval, for the enumeration of attached biofilm cells, the samples were washed with sterile PBS to remove unattached cells and the formed biofilms were removed by scraping with sterile scalpels. The scrapings were collected into $1 \mathrm{~mL}$ sterile distilled water, shaken vigorously and serially diluted in sterile distilled water. Enumeration was done by plating the diluted samples on selective medium (Hektoen enteric agar for Salmonella) by standard spread plate technique, followed by incubation at $37^{\circ} \mathrm{C}$ for $16 \mathrm{hrs}$. After the incubation period, the number of viable cells was counted, and the results were expressed as $\log \mathrm{CFU} / \mathrm{cm}^{2}$. This procedure was repeated at every $48^{\text {th }}$ hour up to $240 \mathrm{hrs}$. Sterility of the surfaces was checked by incubating the surfaces in Luria Bertani medium without adding the bacterial cultures at each time interval.

\section{Analysis of data}

Biofilm-forming ability was compared by analysing the differences in the degree of biofilm formation using one-way ANOVA and Duncan's multiple range test in SPSS (IBM) software (Version 15, IBM). 


\section{RESULTS AND DISCUSSION}

\section{Quantification of biofilm formation using the microtitre plate method}

The ability of different Salmonella isolates to form biofilms on microtiter plates was identified by the development of colour intensity in the microtitre plate (Figure 1). The results revealed that the biofilm formation is different in undiluted TSB and 1:100 diluted TSB. The isolates were classified according to the results using the standard classification and found that there were 07 strong biofilm formers, 11 moderate biofilm formers, and 05 weak biofilm formers in diluted medium (TSB diluted $1: 100$ ) and there were only 04 moderate biofilm formers and 19 weak biofilm formers found in the TSB medium (Table 1).

Biofilm formation in food processing environments has great importance as it can act as a chronic source of microbial contamination which may lead to food spoilage, and disease transmission (Stepanovic et al., 2004; Souza et al., 2014). There are many factors which affect the formation of biofilm, and many researchers have reported that the nutritional condition in the medium is an important factor for the formation of biofilms (Dewanti et al., 1995; Djordjevic et al., 2002; Stepanovic et al., 2003a, Stepanovic et al.,2003b; Ben Miloud Yahia et al., 2018).

Previous studies have revealed that bacteria grown in nutrients-poor medium exhibit stronger biofilm formation than those grown in nutrents-rich medium (Hood and Zottola, 1997; Joseph et al., 2001; Stepanovic et al., 2004; Lamas et at., 2016;
Paytubi et al., 2017; Iniguez-Moreno et al., 2018). The results of the present study also were in line with the previous findings. Therefore, it can be stated that biofilm formation by Salmonella isolates may also occur as a response to the nutritional condition of the growth media.

\section{Presence of genes responsible for biofilm formation}

Screening for the presence of the genes $a d r A$ and gсрA (Figure 2) revealed that both genes were present in all the isolates with biofilm formation ability (Table 1). The synthesis of substances involved in biofilm formation by Salmonella spp. is regulated by a highly complex regulatory network, and this cascade of mechanisms is controlled by a set of genes. Presence of the genes such as $a d r A$ and gсpA is essential to exhibit biofilm formation by Salmonella spp. adrA is needed for the cellulose production and biofilm formation in LB complex media, whereas the gсpA gene is important in biofilm formation in nutrient deficient environments (Solano et al., 2002; Bhowmick et al., 2011; Seixas et al., 2014; Lamas et al., 2016). As the two genes were present in all isolates it could be further confirmed that the presence of both $a d r A$ and $g c p A$ genes is essential for biofilm formation by Salmonella spp.

\section{Biofilm formation by isolates of Salmonella spp. on different surfaces}

The biofilm-forming ability of selected isolates at different time points on different surfaces is given in Tables 2, 3 and 4.

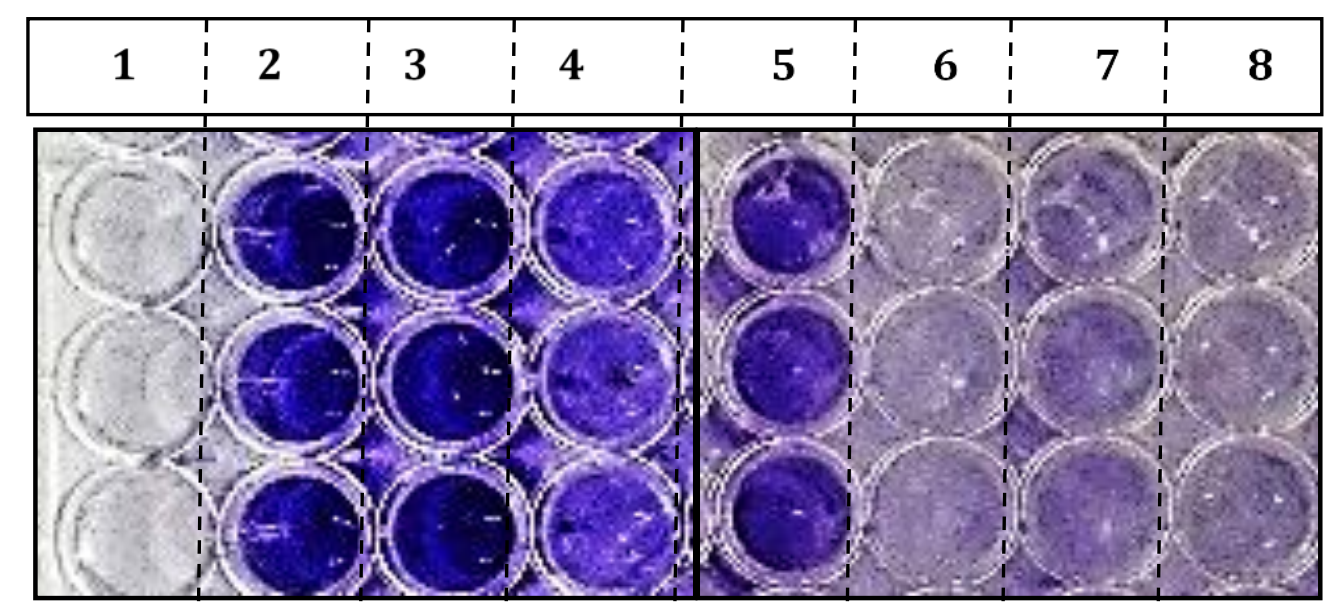

Figure 1: Quantification of biofilm using the microtitre plate method.

Note: 1 . Negative control; $2 \& 3$. Strong biofilm formers; 4 \& 5. Moderate biofilm formers; 6,7 \& 8: Weak biofilm formers 
Table 1: Quantification of biofilm formation by different Salmonella isolates and presence of different genes ( $a d r A$ and $g c p A$ ) involved in biofilm formation

\begin{tabular}{|c|c|c|c|c|c|c|}
\hline \multirow[b]{2}{*}{ Isolate } & \multicolumn{4}{|c|}{ Mean OD } & \multicolumn{2}{|c|}{$\begin{array}{l}\text { Presence of biofilm } \\
\text { associated genes }\end{array}$} \\
\hline & TSB (1:100) & & TSB & & AdrA & gсpA \\
\hline S1 & $0.173 \pm 0.016$ & Moderate & $0.081 \pm 0.002$ & Weak & + & + \\
\hline S2 & $0.167 \pm 0.018$ & Moderate & $0.084 \pm 0.003$ & Weak & + & + \\
\hline S3 & $0.134 \pm 0.022$ & Moderate & $0.074 \pm 0.005$ & Weak & + & + \\
\hline S4 & $0.325 \pm 0.032$ & Strong & $0.109 \pm 0.016$ & Moderate & + & + \\
\hline S5 & $0.173 \pm 0.015$ & Moderate & $0.085 \pm 0.006$ & Weak & + & + \\
\hline S6 & $0.280 \pm 0.033$ & Strong & $0.088 \pm 0.003$ & Weak & + & + \\
\hline S7 & $0.183 \pm 0.027$ & Moderate & $0.094 \pm 0.015$ & Weak & + & + \\
\hline S8 & $0.220 \pm 0.022$ & Moderate & $0.092 \pm 0.011$ & Weak & + & + \\
\hline S9 & $0.267 \pm 0.022$ & Moderate & $0.090 \pm 0.006$ & Weak & + & + \\
\hline S10 & $0.167 \pm 0.013$ & Moderate & $0.098 \pm 0.009$ & Moderate & + & + \\
\hline S11 & $0.090 \pm 0.008$ & Weak & $0.073 \pm 0.006$ & Weak & + & + \\
\hline S12 & $0.216 \pm 0.030$ & Strong & $0.100 \pm 0.011$ & Moderate & + & + \\
\hline S13 & $0.213 \pm 0.022$ & Strong & $0.083 \pm 0.008$ & Weak & + & + \\
\hline S14 & $0.070 \pm 0.034$ & Weak & $0.078 \pm 0.036$ & Weak & + & + \\
\hline S15 & $0.232 \pm 0.021$ & Strong & $0.089 \pm 0.008$ & Weak & + & + \\
\hline S16 & $0.182 \pm 0.037$ & Moderate & $0.087 \pm 0.011$ & Weak & + & + \\
\hline S17 & $0.162 \pm 0.014$ & Moderate & $0.089 \pm 0.011$ & Weak & + & + \\
\hline $\mathrm{S} 18$ & $0.128 \pm 0.101$ & Moderate & $0.058 \pm 0.031$ & Weak & + & + \\
\hline S19 & $0.040 \pm 0.006$ & Weak & $0.044 \pm 0.001$ & Weak & + & + \\
\hline S20 & $0.038 \pm 0.002$ & Weak & $0.055 \pm 0.011$ & Weak & + & + \\
\hline S21 & $0.055 \pm 0.039$ & Weak & $0.044 \pm 0.002$ & Weak & + & + \\
\hline S22 & $0.244 \pm 0.022$ & Strong & $0.097 \pm 0.004$ & Moderate & + & + \\
\hline S23 & $0.258 \pm 0.102$ & Strong & $0.083 \pm 0.005$ & Weak & + & + \\
\hline
\end{tabular}

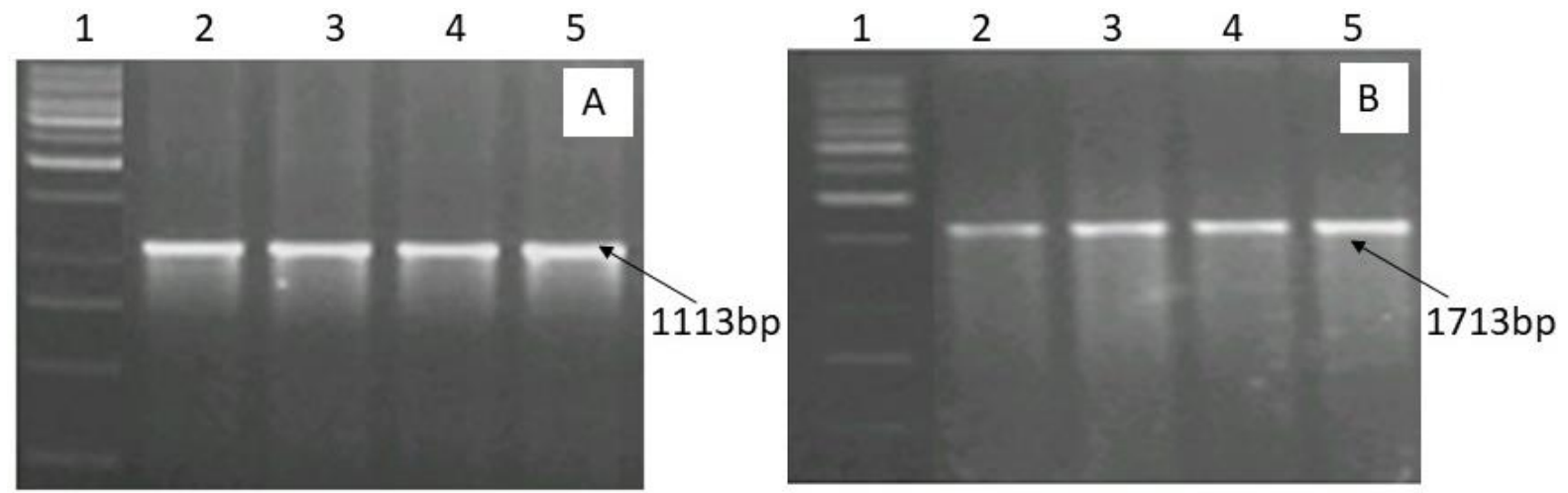

Figure 2: Presence of (A) adrA gene; (B) gcpA gene responsible for biofilm formation in Salmonella isolates.

Note: Lane 1: 1kb DNA ladder, Lane 2-4: Salmonella isolates - S1, S2, S3 and S4 
Table 2: Formation of biofilm by four different Salmonella isolates on plastic surfaces

\begin{tabular}{|c|c|c|c|c|c|}
\hline \multirow{2}{*}{ Isolate } & \multicolumn{5}{|c|}{ Number of biofilm cells (log) at different time intervals } \\
\hline & 48 hours & 96 hours & 144 hours & 192 hours & 240hours \\
\hline S23 & $5.19 \pm 0.01^{b}$ & $6.19 \pm 0.02^{b}$ & $6.41 \pm 0.01^{b}$ & $7.53 \pm 0.01^{b}$ & $7.43 \pm 0.01^{b}$ \\
\hline S6 & $5.20 \pm 0.02 b$ & $6.21 \pm 0.03^{b}$ & $6.39 \pm 0.01^{b}$ & $7.53 \pm 0.01^{b}$ & $7.45 \pm 0.01^{b}$ \\
\hline S4 & $5.29 \pm 0.01^{\mathrm{c}}$ & $6.28 \pm 0.01^{c}$ & $6.48 \pm 0.02^{c}$ & $7.56 \pm 0.00^{c}$ & $7.54 \pm 0.00^{c}$ \\
\hline S8 & $5.09 \pm 0.01^{\mathrm{a}}$ & $6.10 \pm 0.00^{\mathrm{a}}$ & $6.30 \pm 0.00^{\mathrm{a}}$ & $7.39 \pm 0.01^{\mathrm{a}}$ & $7.41 \pm 0.00^{\mathrm{a}}$ \\
\hline
\end{tabular}

Note: Values in the same columns (differ for each surface) with different superscripts are statistically significantly different at $95 \%$ confidence interval

Table 3: Formation of biofilm by four different Salmonella isolates on glass surfaces

\begin{tabular}{cccccc}
\hline & \multicolumn{5}{c}{ Number of biofilm cells (log) at different time intervals } \\
\hline Isolate & $\mathbf{4 8 ~ h o u r s ~}$ & $\mathbf{9 6}$ hours & $\mathbf{1 4 4}$ hours & $\mathbf{1 9 2 ~ h o u r s}$ & $\mathbf{2 4 0}$ hours \\
\hline S23 & $5.12 \pm 0.01^{\mathrm{b}}$ & $6.11 \pm 0.03^{\mathrm{a}, \mathrm{b}}$ & $6.21 \pm 0.03^{\mathrm{b}}$ & $7.37 \pm 0.01^{\mathrm{b}}$ & $7.36 \pm 0.02^{\mathrm{b}}$ \\
S6 & $5.15 \pm 0.00^{\mathrm{c}}$ & $6.14 \pm 0.03^{\mathrm{b}}$ & $6.21 \pm 0.01^{\mathrm{b}}$ & $7.37 \pm 0.01^{\mathrm{b}}$ & $7.36 \pm 0.01^{\mathrm{b}}$ \\
S4 & $5.27 \pm 0.00^{\mathrm{d}}$ & $6.23 \pm 0.02^{\mathrm{d}}$ & $6,42 \pm 0.02^{\mathrm{c}}$ & $7.46 \pm 0.01^{\mathrm{c}}$ & $7.45 \pm 0.01^{\mathrm{c}}$ \\
S8 & $5.02 \pm 0.01^{\mathrm{a}}$ & $6.05 \pm 0.01^{\mathrm{b}}$ & $6.12 \pm 0.00^{\mathrm{a}}$ & $7.29 \pm 0.01^{\mathrm{a}}$ & $7.29 \pm 0.01^{\mathrm{a}}$ \\
\hline
\end{tabular}

Note: Values in the same columns (differ for each surface) with different superscripts are statistically significantly different at $95 \%$ confidence interval

Table 4: Formation of biofilm by four different Salmonella isolates on glass surfaces

\begin{tabular}{cccccc}
\hline \multirow{2}{*}{ Isolate } & \multicolumn{5}{c}{ Number of biofilm cells (log) at different time intervals } \\
\cline { 2 - 6 } & $\mathbf{4 8 ~ h o u r s}$ & $\mathbf{9 6 ~ h o u r s}$ & $\mathbf{1 4 4}$ hours & $\mathbf{1 9 2 ~ h o u r s}$ & $\mathbf{2 4 0}$ hours \\
\hline S23 & $5.03 \pm 0.01^{\mathrm{b}}$ & $6.05 \pm 0.02^{\mathrm{a}, \mathrm{b}}$ & $6.08 \pm 0.01^{\mathrm{b}}$ & $7.24 \pm 0.01^{\mathrm{b}}$ & $7.18 \pm 0.03^{\mathrm{b}}$ \\
$\mathrm{S} 6$ & $5.06 \pm 0.02^{\mathrm{b}}$ & $6.05 \pm 0.01^{\mathrm{a}, \mathrm{b}}$ & $6.09 \pm 0.01^{\mathrm{b}}$ & $7.25 \pm 0.01^{\mathrm{b}}$ & $7.20 \pm 0.02^{\mathrm{b}}$ \\
$\mathrm{S} 4$ & $5.18 \pm 0.02^{\mathrm{c}}$ & $6.11 \pm 0.03^{\mathrm{c}}$ & $6.29 \pm 0.01^{\mathrm{c}}$ & $7.31 \pm 0.01^{\mathrm{c}}$ & $7.32 \pm 0.01^{\mathrm{c}}$ \\
$\mathrm{S} 8$ & $4.96 \pm 0.00^{\mathrm{a}}$ & $6.01 \pm 0.00^{\mathrm{a}}$ & $6.01 \pm 0.00^{\mathrm{a}}$ & $7.07 \pm 0.01^{\mathrm{a}}$ & $7.08 \pm 0.00^{\mathrm{a}}$ \\
\hline
\end{tabular}

Note: Values in the same columns (differ for each surface) with different superscripts are statistically significantly different at $95 \%$ confidence interval

According to the results, it can be stated that the isolate S4 and S8 isolates showed significantly the highest and the lowest $(\mathrm{p} \leq 0.05)$ biofilm-forming abilities, respectively compared to all other isolates at all-time points on the three surfaces (Tables 2, 3 and 4). Further, it was also revealed that all the tested isolates showed a significantly higher $(\mathrm{p} \leq 0.05)$ biofilm formation on plastic surfaces (Table 2) than on glass and stainless steel at all the time points (Tables 2, 3 and 4). Formation of biofilm on stainless steel surface was significantly lower $(p \leq 0.05)$ than that on other two surfaces (Tables 2, 3 and 4) in all the tested isolates. However, the isolates S8 and S4 showed the lowest and the highest biofilm formation abilities respectively, on the stainless steel surface too (Tables 2, 3 and 4).

Biofilm formation in food processing environments is of special importance as it has the potential to act as a chronic source of microbial contamination that may lead to food spoilage and/or transmission of diseases. This is especially because the biofilms exhibit enhanced resistance to general cleaning and sanitation practices (Bower and Daeschel, 1999; Joseph et al., 2001). The capability of Salmonella spp. in biofilm formation on plastic, metal, glass, or rubber surfaces were reported in 
many previous studies (Somers et al., 1994; Dhir and Dodd, 1995; Jones and Bradshaw, 1996; Humphrey et al., 1997; Hood and Zottola, 1997; Wong, 1998; Sommer et al., 1999; Chae and Schraft, 2000; Leriche and Carpentier, 2000; Sinde and Carballo, 2000; Joseph et al., 2001; Ben Miloud Yahia et al., 2018). Similarly, all isolated Salmonella spp. formed biofilms on different surfaces such as plastic, glass, and stainless steel in the present study. Biofilm formation by isolates of Salmonella spp. on different surfaces was also evident that Salmonella isolates S4, S6, and S23 (strong biofilm formers) had significantly higher $(P<0.05)$ biofilmforming abilities than the isolate S8 (moderate biofilm former) on different surfaces. Furthermore, these bacteria possessed a high capacity of biofilm formation on plastic surfaces than on glass and stainless steel. These results confirm the earlier findings, which showed that biofilm formation by Salmonella spp. on plastic surfaces is extensive compared to other surfaces such as stainless steel, glass, and rubber used in the food industry (Romling and Rohde, 1999; Joseph et al., 2001; Mireles et al., 2001; Djordjevic et al., 2002; Stepanovic et al., 2003a,b; Stepanovic et al., 2004; Chia et al., 2009).

In general, it is assumed that glass and stainless steel are hydrophilic materials while plastic is a hydrophobic material (Sinde and Carballo, 2000; Donlan 2002). It has been previously shown that Salmonella spp. adhere in high numbers to hydrophobic materials (Cunliffe et al., 1999; Sinde and Carballo, 2000; Donlan 2002). As adhesion is the first step in the complex process of biofilm formation (Donlan 2002), this could be one possible explanation for the high ability of

\section{REFERENCES}

Ausubel, F., Brent, R., Kingston, R.E., Moore, D.D., Seidman, J.G., Smith, J.A. and Struhl, K. (Eds.). (1992). In: Current Protocols in Molecular Biology. Second Edition, Unit. 2.4. Green Publications Associations, New York.

Ben Miloud Yahia, N., Ghorbal, S.K.B., Maalej, L., Chatti, A., Elmay, A., Chihib, N.E. and Landoulsi, A. (2018). Effect of Temperature and Gamma Radiation on Salmonella hadar Biofilm Production on Different Food Contact Surfaces. Journal of Food Quality. Article ID 9141540, 6 pages. https://doi.org/10.1155/2018/ 9141540

Bhowmick, P.P., Devegowda, D., Ruwandeepika, H.D., Fuchs, T.M., Srikumar, S., Karunasagar, I. and Karunasagar, I. (2011). gcpA (stm1987) is
Salmonella spp. to produce biofilm on the plastic surface. Nevertheless, the previous studies have shown that the attachment of bacterial cells to a surface is affected by numerous factors, including the growth medium, motility, growth phase, type and properties of the inert materials, presence of organic materials, temperature, $\mathrm{pH}$, contact time, production of extracellular polysaccharides, and cell-to-cell communication (Chandy and Angles, 2001; Chmielewski and Frank, 2003; Shi and Zhu, 2009; Simoes et al., 2010a, b; Xu et al., 2011).

As plastic, glass, and stainless steel are the commonly used materials to prepare structures in animal slaughterhouses, animal and meat transport structures, and meat processing plants, the knowledge on Salmonella spp. biofilm formation occurring on contact surfaces is vital to take necessary precautions to avoid contamination of meat with this highly pathogenic microorganism.

\section{CONCLUSIONS}

The Salmonella spp. isolated from broiler meat possessed a high capability of forming biofilm on different surfaces. There were $34.8 \%$ strong biofilm forming isolates among them. Plastic surface was more vulnerable to biofilm formation by isolated Salmonella spp. than the glass and stainless steel surfaces. Biofilm formation was significantly lower $(\mathrm{p} \leq 0.05)$ on stainless steel surfaces than on glass surfaces. Thus, serious consideration must be paid in selection of suitable fabrication materials for meat processing, storage and marketing workflows.

critical for cellulose production and biofilm formation on polystyrene surface by Salmonella enterica serovar Weltevreden in both high and low nutrient medium. Microbial Pathogenesis. 50(2), 114-122.

Borges, K.A., Furian, T.Q., de Souza, S.N., Menezes, R., de Lima, D.A., Fortes, F.B.B., Salle, C.T.P., Moraes, H.L.S. and Nascimento, V.P. (2018). Biofilm formation by Salmonella Enteritidis and Salmonella Typhimurium isolated from avian sources is partially related with their in-vivo pathogenicity. Microbial Pathogenesis. 118, 238-241.

Bower, C.K. and Daeschel, M.A. (1999). Resistance responses of microorganisms in food environments. International Journal of Food Microbiology. 50(1-2), 33-44. 
Chae, M.S. and Schraft, H. (2000). Comparative evaluation of adhesion and biofilm formation of different Listeria monocytogenes strains. International Journal of Food Microbiology. 62(1-2), 103-111.

Chmielewski, R.A.N. and Frank, J.F. (2003). Biofilm formation and control in food processing facilities. Comprehensive Reviews in Food Science and Food Safety. 2(1), 22-32.

Chandy, J.P. and Angles, M.L. (2001). Determination of nutrients limiting biofilm formation and the subsequent impact on disinfectant decay. Water Research. 35(11), 2677-2682.

Chia, T.W.R., Goulter, R.M., McMeekin, T., Dykes, G.A. and Fegan, N. (2009). Attachment of different Salmonella serovars to materials commonly used in a poultry processing plant. Food Microbiology. 26(8), 853-859.

Cunliffe, D., Smart, C.A., Alexander, C. and Vulfson, E.N. (1999). Bacterial adhesion at synthetic surfaces. Applied Environmental Microbiology. 65(11), 4995-5002.

Dewanti, R. and Wong, A.C. (1995). Influence of culture conditions on biofilm formation by Escherichia coli 0157: H7. International Journal of Food Microbiology. 26(2), 147-164.

Dhir, V.K. and Dodd, C.E. (1995). Susceptibility of suspended and surface-attached Salmonella enteritidis to biocides and elevated temperatures. Applied Environmental. Microbiology. 61(5), 1731-1738.

Djordjevic, D., Wiedmann, M. and McLandsborough, L.A. (2002). Microtiter plate assay for assessment of Listeria monocytogenes biofilm formation. Applied Environmental Microbiology. 68(6), 2950-2958.

Donlan, R.M. (2002). Biofilms: microbial life on surfaces. Emerging Infectious Diseases. 8(9), 881.

EFSA (European Food Safety Authority). (2017). The European union summary report on trends and sources of zoonoses, zoonotic agents and food-borne outbreaks in 2016. EFSA Journal. 15(12), 1-228.

Feng, G., Cheng, Y., Wang, S.Y., Borca-Tasciuc, D.A., Worobo, R.W. and Moraru, C.I. (2015). Bacterial attachment and biofilm formation on surfaces are reduced by small-diameter nanoscale pores: how small is small enough? npj Biofilms and Microbiomes. 1, 15022.

Galie, S., García-Gutiérrez, C., Miguélez, E.M., Villar, C.J. and Lombó, F. (2018). Biofilms in the food industry: health aspects and control methods. Frontiers in Microbiology. 9, 898.

Garcia, B., Latasa, C., Solano, C., Portillo, F.G.D., Gamazo, C. and Lasa, I. (2004). Role of the GGDEF protein family in Salmonella cellulose biosynthesis and biofilm formation. Molecular Microbiology. 54(1), 264-277.

Hood, S.K. and Zottola, E.A. (1997). Adherence to stainless steel by foodborne microorganisms during growth in model food systems. International Journal of Food Microbiology. 37(2-3), 145-153.

Humphrey, T.J., Wilde, S.J. and Rowbury, R.J. (1997). Heat tolerance of Salmonella Typhimurium DT104 isolates attached to muscle tissue. Letters in Applied Microbiology. 25(4), 265-268.

Iniguez-Moreno, M., Gutiérrez-Lomelí, M., Guerrero-Medina, P.J. and Avila-Novoa, M.G. (2018). Biofilm formation by Staphylococcus aureus and Salmonella spp. under mono and dual-species conditions and their sensitivity to cetrimonium bromide, peracetic acid and sodium hypochlorite. Brazilian Journal of Microbiology. 49(2), 310-319.

Jones, K. and Bradshaw, S.B. (1996). Biofilm formation by the Enterobacteriaceae: a comparison between Salmonella enteritidis, Escherichia coli and a nitrogen-fixing strain of Klebsiella pneumoniae. Journal of Applied Bacteriology. 80(4), 458-464.

Joseph, B., Otta, S.K., Karunasagar, I. and Karunasagar, I. (2001). Biofilm formation by Salmonella spp. on food contact surfaces and their sensitivity to sanitizers. International Journal of Food Microbiology. 64(3), 367-372.

Lamas, A., Fernandez-No, I.C., Miranda, J.M., Vázquez, B., Cepeda, A. and Franco, C.M. (2016). Prevalence, molecular characterization and antimicrobial resistance of Salmonella serovars isolated from northwestern Spanish broiler flocks (2011-2015). Poultry Science. 95(9), 2097-2105.

Lamas, A., Miranda, J.M., Regal, P., Vazquez, B., Franco, C.M. and Cepeda, A. (2018). A comprehensive review of non-enterica 
subspecies of Salmonella enterica. Microbiological Research. 206, 60-73.

Leriche, V. and Carpentier, B. (2000). Limitation of adhesion and growth of Listeria monocytogenes on stainless steel surfaces by Staphylococcus sciuri biofilms. Journal of Applied Microbiology. 88(4), 594-605.

Marques, S.C., Rezende, J.D.G.O.S., Alves, L.A.D.F., Silva, B.C., Alves, E., Abreu, L.R.D. and Piccoli, R.H. (2007). Formation of biofilms by Staphylococcus aureus on stainless steel and glass surfaces and its resistance to some selected chemical sanitizers. Brazilian Journal of Microbiology. 38(3), 538-543.

Merino, L., Procura, F., Trejo, F.M., Bueno, D.J. and Golowczyc, M.A. (2019). Biofilm formation by Salmonella sp. in the poultry industry: Detection, control and eradication strategies. Food Research International. 119, 530-540.

Mireles, J.R., Toguchi, A. and Harshey, R.M. (2001). Salmonella enterica serovar Typhimurium swarming mutants with altered biofilmforming abilities: surfactin inhibits biofilm formation. Journal of Bacteriology. 183(20), 5848-5854.

Paytubi, S., Cansado, C., Madrid, C. and Balsalobre, C. (2017). Nutrient composition promotes switching between pellicle and bottom biofilm in Salmonella. Frontiers in Microbiology. 8, 2160.

Romling, U. and Rohde, M. (1999). Flagella modulate the multicellular behavior of Salmonella Typhimurium on the community level. FEMS Microbiology Letters. 180(1), 91102.

Schonewille, E., Windhorst, D. and Bräuni I. (2012). Biofilm building properties of Salmonella on the poultry farm. International Poultry Production. 20, 13-15.

Seixas, R., Machado, J., Bernardo, F., Vilela, C. and Oliveira, M. (2014). Biofilm Formation by Salmonella enterica Serovar 1, 4[5], 12: i:Portuguese Isolates: A Phenotypic, Genotypic, and Socio-geographic Analysis. Current Microbiology. 68(5), 670-677.

Shi, X. and Zhu, X. (2009). Biofilm formation and food safety in food industries. Trends in Food Science and Technology. 20(9), 407-413.
Simoes, L.C., Simoes, M. and Vieira, M.J. (2010a). Adhesion and biofilm formation on polystyrene by drinking water-isolated bacteria. Antonie Van Leeuwenhoek. 98(3), 317-329.

Simoes, M., Simões, L.C. and Vieira, M.J. (2010b). A review of current and emergent biofilm control strategies. LWT-Food Science and Technology. 43(4), 573-583.

Sinde, E. and Carballo, J. (2000). Attachment of Salmonella spp. and Listeria monocytogenes to stainless steel, rubber and polytetrafluorethylene: the influence of free energy and the effect of commercial sanitizers. Food Microbiology. 17(4), 439-447.

Solano, C., García, B., Valle, J., Berasain, C., Ghigo, J.M., Gamazo, C. and Lasa, I. (2002). Genetic analysis of Salmonella enteritidis biofilm formation: critical role of cellulose. Molecular Microbiology. 43(3), 793-808.

Somers, E.B., Schoeni, J.L. and Wong, A.C. (1994). Effect of trisodium phosphate on biofilm and planktonic cells of Campylobacter jejuni, Escherichia coli 0157: H7, Listeria monocytogenes and Salmonella typhimurium. International Journal of Food Microbiology. 22(4), 269-276.

Sommer, P., Martin-Rouas, C. and Mettler, E. (1999). Influence of the adherent population level on biofilm population, structure and resistance to chlorination. Food Microbiology. 16(5), 503-515.

Souza, E.L.D., Meira, Q.G.S., Barbosa, I.D.M., Athayde, A.J.A.A., Conceição, M.L.D. and Siqueira Júnior, J.P.D. (2014). Biofilm formation by Staphylococcus aureus from food contact surfaces in a meat-based broth and sensitivity to sanitizers. Brazilian Journal of Microbiology. $45(1), 67-75$.

Srey, S., Jahid, I.K. and Ha, S.D. (2013). Biofilm formation in food industries: a food safety concern. Food Control. 31(2), 572-585.

Steenackers, H., Hermans, K., Vanderleyden, J. and De Keersmaecker, S.C. (2012). Salmonella biofilms: an overview on occurrence, structure, regulation and eradication. Food Research International. 45(2), 502-531.

Stepanovic, S., Dakic, I., Opavski, N., Jezek, P. and Ranin, L. (2003a). Influence of the growth medium composition on biofilm formation by 
Staphylococcus sciuri. Annals of Microbiology. 53(1), 63-74.

Stepanovic, S., Cirkovic, I., Mijac, V. and SvabicVlahovic, M. (2003b). Influence of the incubation temperature, atmosphere and dynamic conditions on biofilm formation by Salmonella spp. Food Microbiology. 20, 339343.

Stepanovic, S., Vuković, D., Dakić, I., Savić, B. and Švabić-Vlahović, M. (2000). A modified microtiter-plate test for quantification of staphylococcal biofilm formation. Journal of Microbiological Methods. 40(2), 175-179.

Stepanovic, S., Ćirković, I., Ranin, L. and S vabićVlahović, M. (2004). Biofilm formation by Salmonella spp. and Listeria monocytogenes on plastic surface. Letters in Applied Microbiology. 38(5), 428-432.

Wang, H., Ye, K., Wei, X., Cao, J., Xu, X. and Zhou, G. (2013). Occurrence, antimicrobial resistance and biofilm formation of Salmonella isolates from a chicken slaughter plant in China. Food Control. 33(2), 378-384.

Wang, R., Schmidt, J.W., Harhay, D.M., Bosilevac, J.M., King, D.A. and Arthur, T.M. (2017). Biofilm formation, antimicrobial resistance, and sanitizer tolerance of Salmonella enterica strains isolated from beef trim. Foodborne Pathogens and Disease. 14(12), 687-695.

Winkelstroter, L.K., dos Reis Teixeira, F.B., Silva, E.P., Alves, V.F. and De Martinis, E.C.P. (2014). Unraveling microbial biofilms of importance for food microbiology. Microbial Ecology. 68(1), 35-46.

Wong, K.K., McClelland, M., Stillwell, L.C., Sisk, E.C., Thurston, S.J. and Saffer, J.D. (1998). Identification and sequence analysis of a 27kilobase chromosomal fragment containing a Salmonella pathogenicity island located at 92 minutes on the chromosome map of Salmonella enterica serovar Typhimurium LT2. Infection and Immunity. 66(7), 3365-3371.

Xu, H., He, X. and Ahn, J. (2011). Assessment of antibiotic susceptibilities, genotypic characteristics and biofilm-forming abilities of Staphylococcus aureus and Salmonella Typhimurium. African Journal of Biotechnology. 10(57), 12125-12133. 